\title{
Flora da Paraíba, Brasil: Erythroxylaceae Kunth
}

\author{
Maria Iracema Bezerra Loiola ${ }^{1}$, Maria de Fátima Agra ${ }^{4,3}$, George Sidney Baracho ${ }^{2}$ e \\ Rubens Teixeira de Queiroz ${ }^{1}$
}

Recebido em 3/02/2006. Aceito em 10/11/2006

RESUMO - (Flora da Paraíba, Brasil: Erythroxylaceae Kunth). Neste trabalho apresenta-se o tratamento taxonômico da família Erythroxylaceae como parte do projeto "Flora da Paraíba", que vem sendo realizado com o objetivo de identificar e catalogar as espécies da flora local. Realizaram-se coletas e observações de campo para as identificações, descrições e ilustrações botânicas, que foram efetuadas após estudos morfológicos, com o auxílio da bibliografia especializada, complementados pela análise de fotos de tipos e de espécimes de herbários nacionais e internacionais. Treze espécies do gênero Erythroxylum foram registradas para a área estudada: Erythroxylum caatingae Plowman, E. citrifolium A. St.-Hil, E. nummularia Peyr., E. pauferrense Plowman, E. passerinum Mart., E. pulchrum A. St.-Hil., E. pungens O.E. Schulz, E. revolutum Mart., E. rimosum O.E. Schulz, E. simonis Plowman, E. suberosum var. denudatum O.E. Schulz e E. subrotundum A. St.-Hil. Dentre estas, seis são novas referências para o Estado.

Palavras-chave: Erythroxylaceae, Erythroxylum, flora, taxonomia, Nordeste do Brasil

\begin{abstract}
Flora of Paraíba, Brazil: Erythroxylaceae Kunth). A taxonomic treatment of the Erythroxylaceae family was undertaken as part of the project "Flora da Paraíba" which aims to identify and catalogue the species of the local flora. Botanical identification and illustrations were supported by morphological studies and bibliography, analysis of the types and specimens from national and international herbaria, complemented by field observations. Thirteen species of Erythroxylaceae belonging to the genus Erythroxylum were found in Paraíba state: Erythroxylum caatingae Plowman, E. citrifolium A. St.-Hil, E. nummularia Peyr., E. pauferrense Plowman, E. passerinum Mart., E. pulchrum A. St.-Hil., E. pungens O.E. Schulz, E. revolutum Mart., E. rimosum O.E. Schulz, E. simonis Plowman, E. suberosum var. denudatum O.E. Schulz and E. subrotundum A. St.-Hil. Six of these species are new records for the state.
\end{abstract}

Key words: Erythroxylaceae, Erythroxylum, flora, taxonomy, Northeast Brazil

\section{Introdução}

Erythroxylaceae compreende quatro gêneros e cerca 240 espécies com distribuição pantropical, tendo seus principais centros de diversidade e endemismo na Venezuela, Brasil e Madagascar (Daly 2004). A maioria das espécies pertence ao gênero Erythroxylum P.Browne, que apresenta distribuição ampla encontrado nos quatro continentes, principalmente na América tropical (Plowman 2001). Os outros três gêneros, Aneulophus Benth., Nectaropetalum Engl. e Pinacopodium Exell \& Mendonça, possuem poucas espécies e apresentam distribuição exclusiva na África (Plowman \& Berry 1999; Daly 2004).

A posição sistemática da família e suas afinidades têm apresentado controvérsias, alguns autores como
Stebbins (1974) e Thorne (2000) a posicionaram na ordem Geraniales. Cronquist (1981), por outro lado, colocou Erythroxylaceae na ordem Linales excluindoa de Geraniales, com base principalmente na morfologia foliar, no hábito arbóreo a herbáceo, e na presença de vasos escalariformes. Estudos moleculares recentes (Savolainen et al. 2000; Schwarzbach \& Ricklefs 2000; Soltis et al. 2000), apoiados em vários caracteres morfológicos e anatômicos listados por Dahlgren (1988), evidenciaram a grande afinidade entre Erythroxylaceae e Rhizophoraceae e sugeriram seu posicionamento na ordem Malphiguiales, sensu APG (1998). Na classificação proposta pelo APG (2003), a grande afinidade e o conjunto de caracteres compartilhados pelas duas famílias fizeram com que Erythroxylaceae e Rhizophoraceae fossem consideradas, opcionalmente, como uma só família,

1 Universidade Federal do Rio Grande do Norte, Departamento de Botânica, Ecologia e Zoologia, Campus Universitário, $59072-970$ Natal, RN, Brasil

2 Universidade Federal da Paraíba, Laboratório de Tecnologia Farmacêutica Prof. Delby Fernandes Medeiros, C. Postal 5009, 58051-970 João Pessoa, PB, Brasil

3 Universidade de Pernambuco, Instituto de Ciências Biológicas, Departamento de Biologia, Laboratório de Biologia Vegetal, 50100-130 Recife, PE, Brasil

4 Autor para correspondência: agramf@ltf.ufpb.br 
Rhizophoraceae. De acordo com Judd \& Olmstead (2004) os principais caracteres partilhados pelas duas famílias são: alcalóides dos grupos tropanos e pirrolidínicos, presença de coleteres, gemas terminais protegidas por estípulas, e embriões verdes.

Erythroxylum, com cerca de 230 espécies, é o único gênero representado na região Neotropical, onde aproximadamente 187 espécies são exclusivas (Plowman \& Hensold 2004), tendo como principal centro de diversidade e endemismo a América do Sul, especialmente o Brasil e a Venezuela (Plowman \& Hensold 2004). É um grupo de grande versatilidade ecológica, com espécies encontradas em ambientes úmidos como a Floresta Amazônica e a Floresta Atlântica, e nas regiões semi-áridas, ocorrendo em diferentes níveis de elevações, desde o nível do mar até hábitats montanhosos (Daly 2004).

De acordo com Zuanazzi et al. (2001), o interesse pelo gênero intensificou-se no século XIX, após a descoberta das atividades farmacológicas apresentadas pelas folhas de Erythroxylum coca Lam., que secularmente eram empregadas pelos indígenas da região andina da América do Sul. Quimicamente, o gênero caracteriza-se pela presença de alcalóides do grupo tropano, dentre os quais destaca-se a cocaína, um alcalóide natural produzido por E. coca, que foi empregado como anestésico local em pequenas cirurgias (Bohm et al. 1982; Griffin \& Lin 2000). Entretanto, a cocaína ganhou notoriedade por sua atividade psicoativa no Sistema Nervoso Central (SNC), tornando-se um dos grandes problemas de saúde pública da atualidade (Alagille et al. 2005).

$\mathrm{O}$ gênero caracteriza-se pela presença de plantas lenhosas, arbustos ou árvores, glabras, com catafilos geralmente semelhantes às estípulas. As folhas são alternas e inteiras, com estípulas intrapeciolares. As flores são monoclinas, diclamídeas, pentâmeras e heterostílicas, com 10 estames de filetes unidos na base, formando um tubo que circunda o pistilo. $\mathrm{O}$ ovário é súpero, tricarpelar, trilocular, mas geralmente com apenas um único óvulo desenvolvido. O fruto é uma drupa, vermelha a púrpura.

De acordo com Plowman \& Hensold (2004), o Brasil é um dos principais centros de diversidade e endemismo de Erythroxylum, onde são encontradas cerca de 114 espécies das 187 registradas para a América tropical. Destas, aproximadamente 74 possuem distribuição restrita (M. I. B. Loiola, dados não publicados).

No Brasil, o tratamento mais abrangente para Erythroxylaceae foi realizado por Peyritsch (1878), que descreveu 82 espécies de Erythroxylum, pertencentes a quatro seções, apoiado principalmente no tamanho e forma das folhas, morfologia das sépalas e número de flores na inflorescência. Outras informações são encontradas em floras regionais (Amaral 1980; Plowman 1984; Amaral \& Leoni 1992; Zappi 1995; Vicentini \& Prance 1999; Barbosa \& Amaral 2001; Loiola 2004) e em descrições de novas espécies (Plowman 1983; 1986; 1987; Amaral 1990). Recentemente, a revisão taxonômica de Erythroxylum sect. Rhabdophyllum, com cerca de 52 espécies, sendo a maioria brasileira, foi realizada por M.I.B. Loiola (dados não publicados).

Embora essa família esteja relativamente bem representada e suas espécies possuam aplicações farmacológicas e na medicina popular, estudos sobre Erythroxylaceae na Paraíba são inexistentes. O presente trabalho teve como objetivo a realização do tratamento taxonômico da família, representada pelo gênero Erythroxylum, como parte do Projeto Flora Paraibana.

\section{Material e métodos}

Este estudo baseou-se em análises morfológicas comparativas, utilizando-se materiais herborizados pertencentes aos acervos dos herbários Jayme Coelho de Moraes (EAN) e Prof. Lauro Pires Xavier (JPB), ambos da Universidade Federal da Paraíba, e Prof. Dárdano de Andrade Lima (IPA), Instituto de Pesquisas Agropecuárias de Pernambuco, complementado por observações de campo. As identificações das espécies foram feitas por meio de comparações dos exemplares com descrições originais encontradas na bibliografia (Martius 1843; Peyritsch 1878; Schulz 1907; Plowman 1986; 1987; Loiola 2004), complementados pela análise de espécimes e tipos dos herbários a seguir relacionados, de acordo com Holmgren et al. (1990): EAN, ESAL, F, IAN, IPA, K, NY, P, R, RB, UFRPE, SP e SPSF.

As abreviaturas dos autores dos táxons estão de acordo com Brummitt \& Powell (1992). As informações sobre o hábito das plantas, cor das flores e frutos, fenologia, distribuição geográfica e nome popular foram obtidos dos rótulos das exsicatas consultadas e/ou complementados com dados da literatura. A análise morfológica do material botânico e a confecção das pranchas ilustrativas foram realizadas com o auxílio de estereomicroscópio e câmara-clara, Zeiss. O tratamento taxonômico seguiu o modelo proposto para a Flora Paraibana (Cabral \& Agra 1999; Nurit et al. 2005). 


\section{Resultados e discussão}

Erythroxylaceae Kunth, Nov. Gen. Sp. (quarto ed.) 5: 175.1822.

Árvores, arvoretas, arbustos e subarbustos, glabros, inermes. Folhas alternas, raro opostas (Aneulophus), inteiras, estipuladas, pecioladas; estípulas persistentes ou caducas. Flores solitárias ou fasciculadas axilares, sésseis a pedunculadas, surgindo de bractéolas escariosas pequenas, pediceladas ou subsésseis, actinomorfas, freqüentemente com heterostilia; cálice persistente, sépalas 5, valvares, unidas na base; pétalas 5, livres, alternas com as sépalas, imbricadas na prefloração, geralmente com apêndices na superficie adaxial. Estames geralmente 10, filetes unidos na base formando um tubo curto, anteras ditecas, deiscência longitudinal. Ovário 1, súpero, (2-) 3-locular, geralmente só um lóculo ovulífero, óvulo solitário (2 em Nectaropetalum), axial, pêndulo, epítropo, estilete (2-)3 livres ou soldados desde a base, estigma capitado, raramente subséssil. Fruto drupa, com 1 semente, raro cápsula, com 2-3 sementes (em Aneulophus), ambos cálice e filetes persistentes na base do fruto; embrião reto, com ou sem endosperma.

Erythroxylaceae é constituída dos gêneros Aneulophus, Erythroxylum, Nectaropetalum e Pinacopodiu, sendo os Aneulophus, Nectaropetalum e Pinacopodium com distribuição restrita a África tropical (Plowman 2001). Erythroxylum é o maior e mais representativo, apresentando ampla distribuição nas regiões tropicais de todo o mundo, tendo como centro de diversidade e endemismo a América do Sul. No Brasil a família está representada apenas pelo gênero Erythroxylum, com cerca de 114 espécies (M.I.B. Loiola, dados não publicados).

Erythroxylum P. Browne, Civ. Nat. Hist. Jamaica 278. 1756.

Árvores até subarbustos, perenifólios; córtex em geral estriado, raro suberoso, escasso a densamente lenticelado. Ramos com catafilos persistentes, dísticos ou imbricados. Estípulas intrapeciolares, persistentes ou caducas, estriadas ou não, (0)-2-3 setulosas, margem inteira a densamente vilosofimbriolada, dorsalmente 2-costado, frequientemente similares aos catafilos. Folhas alternas, geralmente dísticas, simples, pecioladas; lâmina foliar inteira, glabra, areolada ou não, membranácea, cartácea ou coriácea, venação involuta. Inflorescências em geral fasciculadas, às vezes reduzidas a uma flor, na axila das folhas e/ou catafilos. Flores pediceladas ou subsésseis, diclamídeas, monoclinas, heterostílicas; cálice 5-lobado, sépalas curtas a longamente concrescidas na base, persistentes; corola com prefloração contorcida; pétalas 5 , caducas, alternas aos lobos do cálice, com uma lígula 2-lobada na superfície interna. Estames 10, em dois verticilos de 5 , filetes de dois tamanhos diferentes, os mais externos alternipétalos, concrescidos na base formando um tubo persistente (urcéolo), circundando o ovário. Ovário 3-carpelar, 3-locular, com apenas um lóculo desenvolvido; óvulo 1, pêndulo; estiletes 3, livres ou parcialmente concrescidos; estigmas subcapitados. Fruto drupa, carnosa, vermelha; semente 1 , freqüentemente oblongo-elíptica.

É o maior gênero da família Erythroxylaceae, com cerca de 230 espécies e ampla distribuição, nas regiões tropicais da Austrália, Ásia, África e Américas. Aproximadamente 187 espécies, que corresponde a $81 \%$, são exclusivas das regiões Neotropicais (Plowman \& Hensold 2004), tendo como principais centros de diversidade a Venezuela e o Brasil, com 40 e 115 espécies, respectivamente (Daly 2004; M.I.B. Loiola, dados não publicados). No Brasil o gênero possui cerca de 74 espécies com distribuição restrita, que corresponde a $40 \%$ das espécies da região Neotropical, encontradas nos mais diversos tipos de vegetação do país, ocorrendo na Amazônia, Floresta Atlântica, e nas florestas secas do Cerrado e da Caatinga (Plowman \& Hensold 2004).

Para a Paraíba foram registradas 13 (treze) espécies: E. caatingae Plowman, E. citrifolium A. St.-Hil, E. nummularia Peyr., E. pauferrense Plowman, E. passerinum Mart., E. pulchrum A. St.-Hil., E. pungens O.E. Schulz, E revolutum Mart., E. simonis Plowman, E. suberosum var. denudatum O.E. Schulz, E. subrotundum A. St.-Hil. e E. squamatum $\mathrm{Sw}$. encontradas nas diversas formações do Estado, como as florestas úmidas da Mata Atlântica, Brejos de Altitude, Matas Serranas, Restingas e áreas mais secas da Caatinga, como o Cariri Paraibano. 
Chave para as espécies

1. Estípulas enérveas

2. Tubo estaminal maior que os lobos do cálice; estípulas 3-setulosas; lâmina foliar com 30-42 mm de largura 6. E. pulchrum

2. Tubo estaminal do mesmo tamanho ou menor que os lobos do cálice; estípulas 2-setulosas; lâmina foliar com 16-29 mm de largura

3. Pecíolo 6-8 mm compr.; estípula menor que o pecíolo 1. E. caatingae

3. Pecíolo 1-2 mm compr.; estípula do mesmo tamanho ou maior que o pecíolo

4. Lâmina foliar cartácea, elíptica ou raro suborbicular, com ápice retuso ..... 3. E. nummularia

4. Lâmina foliar membranácea, obovada a largo-elíptica, com ápice arredondado

13. E. subrotundum

1. Estípulas estriado-nervadas

5. Flores subsésseis; Lâmina foliar coriácea, com margens freqüentemente revolutas 8. E. revolutum

5. Flores pediceladas; Lâmina foliar membranácea a coriácea, com margens planas

6. Tubo estaminal maior que os lobos do cálice 10. E. simonis

6. Tubo estaminal menor ou do mesmo tamanho dos lobos do cálice

7. Ramos patentes (formando $45^{\circ}$ ), freqüentemente enegrecidos 7. E. pungens

7. Ramos não patentes, castanhos, avermelhados, cinéreos, alvacentos ou acinzentados

8. Lâmina foliar com ápice cuspidado; catafilos numerosos e adensados, lenhosos nos ramos maduros

11. E. squamatum

8. Lâmina foliar com ápice acuminado, agudo, obtuso ou arredondado; catafilos em geral poucos e esparsos, se numerosos e aproximados, nunca lenhosos nos ramos maduros

9. Lobos do cálice triangulares a deltóides

10. Drupa sem sulcos; lâmina foliar membranácea 2. E. citrifolium

10. Drupa 6-sulcada; lâmina foliar cartácea a subcoriácea

11. Estiletes unidos nas flores longistilas e brevistilas

5. E. pauferrense

11. Estiletes livres nas flores longistilas e brevistilas

4. E. passerinum

9. Lobos do cálice oblongos a obovais

12. Lâmina foliar coriácea, obovada; venação secundária pouco evidente em ambas as faces 12. E. suberosum var. denudatum

12. Lâmina foliar cartácea, elíptica ou oblonga; venação secundária impressa na face adaxial e proeminente na face abaxial 9. E.rimosum

1. Erythroxylum caatingae Plowman, Fieldiana, Bot. 19: 5, f. 3, 1987.

Fig. 1-3

Arbusto a arvoretas, até $3,0 \mathrm{~m}$ alt.; ramos não patentes, castanho-avermelhados e com poucas lenticelas quando jovens, esparsas; ramos maduros enegrecidos, com maior densidade de lenticelas. Catafilos menores que as estípulas, adensados na base dos ramos jovens. Estípulas 3-4 mm compr., enérveas, estreitamente triangulares, curtamente 2-setulosas, margem inteira, menores que o pecíolo. Folha discolor; pecíolo 6-8 mm compr., cilíndricos, pouco maior que as estípulas; lâmina $31-57 \times 21-25 \mathrm{~mm}$, membranácea, quando jovem, e cartácea na maturidade, obovada a oblonga, ápice arredondado a retuso, base cuneada, margem plana; venação secundária finamente reticulada, proeminente na face adaxial, impressa abaxialmente. Fascículos, 1-3 flores na axila das folhas e/ou catafilos. Bractéolas 1,2-1,5 mm, ovadas, côncavas, paleáceas. Pedicelo 1-2 mm compr., 5-costado, subcrasso. Flores 4,0-6,0 mm compr., pediceladas; lobos do cálice 1,0-1,5×0,9-1,0 mm, triangulares; pétala 1,7-2,2 mm compr., esbranquiçada, ovada; tubo estaminal 0,9-1,2 mm compr., menor que os lobos do cálice. Flores brevistilas: estames 1,8-2,0 mm compr.; anteras 0,5-0,6×0,4-0,5 mm, elípticas; estiletes 1,0-1,2 mm compr., brevemente conados na base. Flores longistilas: estames opositissépalos 0,6-0,7 mm compr.; alternissépalos 1,1-1,2 mm compr.; anteras 0,5-0,6×0,4-0,5 mm, 
elípticas. Ovário 1,4-1,5×0,8-1,0 mm, obovóide; estiletes 2,0-2,5 mm compr., unidos na base. Drupa 8-9×5-6 mm, elipsóide, 3 sulcada longitudinalmente; pedicelo frutífero 6,0-9,0 mm compr., 5-6-costado.

Erythroxylum caatingae possui distribuição restrita ao Nordeste do Brasil, somente registrada para os Estados da Bahia, Ceará, Paraíba, Pernambuco e Rio Grande do Norte (Plowman \& Hensold, 2004). A presença desta espécie associada a ambientes de caatinga foi reportada por M.I.B. Loiola (dados não publicados). Sua ocorrência na Paraíba está restrita às coletas na caatinga, em área de afloramentos rochosos (Fig. 35A). Amostras com flores foram coletadas em março.

Material examinado selecionado: BRASIL. Paraíba: Piancó, Serra de Piancó, estrada entre Nova Floresta e Picuí, ca.10 km de Picuí, III/2002, fl., Agra et al. 5666 (JPB); Monte Horebe, serra em direção Mauriti (CE), III/2000, fr. jovens, Barbosa et al. 2009 (JPB); ibid., III/2000, fr., Barbosa et al. 2024 (JPB).

2. Erythroxylum citrifolium A. St.-Hil., Fl. Bras. Merid. 2: 94, 1829.

Fig. 4-6

Arbusto 1,0-1,2 a arvoreta $5 \mathrm{~m}$ alt.; ramos não patentes, acinzentados a castanhos, recobertos por lenticelas elípticas e esbranquiçadas. Catafilos do mesmo tamanho das estípulas, laxamente distribuídos nos ramos. Estípulas 4-6 mm compr., estriado-nervadas, maiores que o pecíolo, estreitamente triangulares, 3-setulosas, margem plana, levemente discolor; pecíolo 2-4 mm compr., menor que as estípulas; lâmina 62-101×21-52 mm, membranácea, elíptica a estreitamente elíptica, ápice acuminado, base aguda, margem inteira; venação secundária finamente reticulada, impressa na face adaxial e proeminente na face abaxial. Fascículos, 1-9 flores, na axila das folhas e/ou catafilos; bractéolas 0,8-1,0 mm compr., triangulares, côncavas, paleáceas; pedicelo 2,8-3,5 mm compr., 5-6-costado. Flores 5,5-7,0 mm compr., pediceladas; lobos do cálice $0,8-1,0 \times 0,8-1 \mathrm{~mm}$, triangulares, com ápice agudo a curto-acuminado; pétala 1,8-2,2 mm compr., amarelada, ovada, ápice arredondado; tubo estaminal 0,6-0,8 mm compr., menor que os lobos do cálice. Flores brevistilas: estames 2,0-2,2 mm compr., branco-esverdeados; anteras 0,4-0,5×0,4-0,5 mm, cordado-orbiculares, esverdeadas; estiletes 0,6-1 mm compr., livres. Flores longistilas: estames opositissépalos 0,8-1,2 mm compr.; alternissépalos 1,2-1,6 mm compr., anteras 0,4-0,5x 0,4-0,5 mm, cordado-orbiculares. Ovário 1,2-1,5×
1-1,2 mm, estreito obovóide a largamente obovóide; estiletes 2,5-3,1 mm compr., livres. Drupa 7,5-8,5×3-4 mm, elíptica, aguda no ápice, sem sulcos; pedicelo frutífero 3,5-5,5 mm compr., 5-6-costado.

Espécie Neotropical, com ampla distribuição, ocorrendo desde o México até o sul do Brasil. Embora habite preferencialmente os ambientes de florestas úmidas, esta espécie foi encontrada em todas as regiões brasileiras, compondo os mais variados tipos de vegetação (M.I.B. Loiola, dados não publicados). Na Paraíba, E. citrifolium só foi encontrada em remanescentes de Floresta Atlântica e em Brejos de Altitude (Fig. 35B), em elevações que variam de 700-800. Amostras com flores foram coletadas em abril, e com frutos em abril e outubro.

Material examinado selecionado: BRASIL. Paraíba: Areia, Escola de Agronomia do Nordeste, X/1943, fr., Vasconcelos s.n. (SPSF420); ibid., 1943, fl., Moraes 4 (EAN); ibid., IV/1993, fl., Félix et al. 5721 (EAN); João Pessoa, Praia da Penha, IV/1993, fr., Moura 958 (JPB); ibid., mata do Buraquinho, III/1992, fl., Barbosa 1265 (JPB); ibid., Jardim Botânico, XI/2003, est., Gadelha Neto \& Luz 1036 (JPB).

3. Erythroxylum nummularia Peyr., in Mart., Fl. bras. 12(1):133, t. 23, f. 3, 1878.

Fig. $7-10$

Arvoreta, 1,5-2,5 m alt.; ramos não patentes, longos e curtos, acinzentados, verruculosos, densamente recoberto por lenticelas elípticas, brancas a amareladas. Catafilos do mesmo tamanho que as estípulas, congestos ao longo dos ramos curtos. Estípulas 1,6-2,2 mm compr., enérveas, triangulares, arredondadas no ápice, 2 -setulosas, margem inteira. Folha levemente discolor; pecíolo subséssil, 1,0-1,5 mm compr.; lâmina 18-29x 16-21 mm, cartácea, elíptica, raro suborbicular, ápice retuso, base aguda, margem plana; venação secundária finamente reticulada, proeminente na face superior. Fascículos, 1-5 flores, na axila das folhas e/ou catafilos. Bractéolas 0,7-0,9 mm compr., triangulares, côncavas, cartáceas. Pedicelo 2,0-2,5 mm compr., 5-costado, crasso. Flores 4,0-5,0 mm compr., pediceladas; lobos do cálice 1,0-1,2×0,6-0,8 mm, triangulares, ápice agudo; pétala 2,0-2,2×0,9-1,0 mm, esbranquiçada, obovada, côncava, tubo estaminal 1,0-1,2×1,0-1,2 mm compr., do mesmo tamanho dos lobos do cálice. Flores brevistilas: estames 2,2-2,5 mm compr.; anteras $0,2-0,3 \times 0,1 \mathrm{~mm}$, elípticas. Flores longistilas não observadas. Ovário 1-1,2×0,3 mm, elipsóide; estiletes 1-1,2 mm compr., livres. Drupa não observada. 
Espécie exclusiva do Nordeste do Brasil, geralmente associada ao semi-árido, encontrada nos Estados da Bahia, Ceará, Pernambuco e Rio Grande do Norte, geralmente associada ao semi-árido (Plowman \& Hensold 2004). Na Paraíba a espécie foi coletada em um remanescente de Floresta Atlântica e em um enclave de Floresta Serrana (Fig. 35C), em altitudes de 0-1.100 m. Sua ocorrência na Paraíba está sendo referida pela primeira vez, como também sua presença em ambiente de floresta úmida. Amostras com flores foram coletadas em janeiro, março e novembro, e com frutos em fevereiro.

Material examinado selecionado: BRASIL. Paraíba: Mamanguape, Tarana, Sema II, XI/1991, fl., Félix \& Miranda 4575 (EAN); Maturéia, Pico do Jabre, $7^{\circ} 11^{\prime} 10^{\prime \prime} \mathrm{S}, 37^{\circ} 25^{\prime} 53^{\prime \prime} \mathrm{W}$, ao norte da sede da TELPA, I/1998, fl., Agra et al. 4797 (JPB); ibid., II/1998, fr., Agra et al. 5090 (JPB); I/1998, fl., Agra et al. 4604 (JPB); III/1994, fl., Agra et al. 2614 (JPB).

\section{Erythroxylum passerinum Mart., Beitr.} Erythroxylon 106, 1840.

Fig. 12-13

Arbusto 0,8-1,0 m alt.; ramos não patentes, cinéreos a castanho-cinéreos, com lenticelas elípticas, amareladas. Catafilos do mesmo tamanho que as estípulas, laxos ao longo dos ramos e/ou congestos na base da porção jovem. Estípulas 2,5-3,5 mm compr., estriado-nervadas quando jovens, triangulares, curtamente 3-setulosas, margem inteira, menores que o pecíolo. Folha discolor; pecíolo 1,5-4,0 mm compr.; lâmina 23-65×33-42 mm, cartácea a coriácea, em geral largamente elíptica, ápice agudo, base aguda, margem plana; venação secundária finamente reticulada na face adaxial, proeminentes na abaxial. Fascículos, 3-9 flores na axila das folhas e/ou catafilos. Bractéolas 0,8-1,0 mm, triangulares, côncavas, membranáceas. Pedicelo 3-6mm compr., 5-costado. Flores 4,5-6,2 mm compr., pediceladas; lobos do cálice triangulares a deltóides, 1,0-1,3×0,6-0,8 mm, côncavos, agudos no ápice; pétala 2,5-3,2×1,3-1,5 mm, amarelada, oblonga, côncava, ápice arredondado; tubo estaminal 0,7-1,0 mm compr., menor que os lobos do cálice. Flores brevistilas: estames 2,7-3,0 mm compr.; anteras 0,4-0,5x 0,3-0,4 mm, elípticas;estiletes 1,2-1,5 mm compr., livres. Flores longistilas: estames opositissépalos 1,2-1,5 mm compr.; alternissépalos 1,7-2,0 mm compr.; anteras 0,4-0,5×0,3-0,4 mm, elípticas. Ovário 1,2-1,4× 0,9-1,0 mm, obovóide; estiletes 3,5-4,0 mm compr., livres. Drupa 8,0-9,0×4,0-5,0 mm, ovóide a oblongo- elipsóide, 6-sulcada longitudinalmente, vermelha; pedicelo frutífero 5,0-6,5 mm compr., levemente 5-6 costado.

Erythroxylum passerinum possui distribuição exclusiva no Brasil, ocorrendo nas regiões Nordeste (Alagoas, Bahia, Pernambuco e Sergipe) e Sudeste (Espírito Santo e Rio de Janeiro), em ambientes de restinga ou em pequenas manchas de cerrados litorâneos (M.I.B. Loiola, dados não publicados). Na Paraíba a espécie só foi coletada em um remanescente de Floresta Atlântica e em área de Brejos de Altitude, em elevações que variam de 40-600 m de altitude (Fig. 35D). Sua ocorrência na Paraíba está sendo aqui referida pela primeira vez. Amostras com flores foram coletadas em maio e dezembro, e com frutos em maio.

Material examinado selecionado: BRASIL.

Paraíba: Areia, Escola de Agronomia do Nordeste, s.d., fl., Vasconcelos 381 (K); Mamanguape, Campo Grande, Sema 2, XII/1989, fl., Félix \& Santana 2529 (EAN, JPB); Mataraca, V/1990, fl., Oliveira Filho 411 (ESAL); ibid., V/1990, fl., Oliveira Filho 433 (ESAL); Rio Tinto, Mata do Maracujá, V/1989, fr., Miranda et al. s.n. (JPB 22026).

5. Erythroxylum pauferrense Plowman, Brittonia 38(3): 193, f. 3, 1986.

Fig. 16-17

Nome popular: guarda-orvalho (Plowman 1986).

Arbusto ou arvoreta, 1,5-4 m alt.; ramos não patentes, acinzentados, longitudinalmente estriados, lenticelas elípticas, amareladas. Catafilos do mesmo tamanho das estípulas, dísticos, na base da porção jovem e/ou congestos no ápice dos ramos curtos. Estípulas 2,0-2,5 mm compr., estriado-nervadas, triangulares, ápice truncado, obtuso, 3-setulosas, margem inteira., do mesmo tamanho do pecíolo. Folha levemente discolor; pecíolo 2,0-2,5 mm compr.; lâmina foliar 21-62×16-34 mm, cartácea, em geral elíptica, às vezes oboval, ápice agudo a obtuso, curtamente mucronulado, base aguda a cuneada, margem plana; venação secundária reticulada, mais proeminente na face abaxial. Fascículos, 1-4 flores na axila das folhas e/ou catafilos. Bractéolas 0,6-0,9 mm compr., triangulares, côncavas. Pedicelo 2,5-4,5mm compr., 5-costado. Flores 4-6,5mm compr., pediceladas; lobos do cálice triangulares, 1,0-1,2×0,8-1,0 mm, ápice agudo a acuminado; pétala 1,5-2,0×1,0-1,2 mm, alvoamarelada, oboval-oblonga, arredondada no ápice, côncava, alvo-amarelada; tubo estaminal 0,8-1,2× 1,5-1,7 mm, menor que os lobos do cálice. Flores brevistilas: estames 1,8-2,0 $\mathrm{mm}$ compr.; estiletes 
0,9-1,0 mm compr., unidos 0,3-0,5 $\mathrm{mm}$ na base. Flores longistilas: estames opositissépalos 0,5-0,8 mm compr.; anteras ; alternissépalos 1,0-1,4 mm compr., anteras Ovário 1,2-1,7×0,7-0,8 mm, elipsóide; estiletes 2,5-2,8 mm compr., unidos 1,0-1,5 mm na base. Drupa 7,5-9,0×3,2-4,5 mm, ovóide, 6-sulcada, vermelha; pedicelo frutífero 3,5-3,8 $\mathrm{mm}$.

Erythroxylum pauferrense é endêmica da região Nordeste do Brasil com ocorrência confirmada apenas no estado da Paraíba, de onde provém o espécime tipo, no município de Areia, área de Brejos de Altitude, em elevações de 500 a $660 \mathrm{~m}$ de altitude (Fig. 35E), sendo encontrada no interior da floresta. A espécie possui grande afinidade com E. simonis, também encontrada na Paraíba, da qual pode distinguir-se pelos seguintes caracteres: estiletes parcialmente soldados até a metade, nos dois tipos florais; tubo estaminal menor que o cálice; e o fruto 6-sulcado. Em E. simonis os estiletes são livres, nos dois tipos florais; o tubo estaminal é maior que o cálice e o fruto é liso. Amostras com flores foram coletadas em março, junho e julho, e com frutos em março e maio.

Material examinado selecionado: BRASIL. Paraíba: Areia, 658'S, 3542'W, Mata de Pau Ferro, picada dos postes, XII/1980, st., Fevereiro et al. M374 (K); ibid., Escola Superior de Agronomia do Nordeste, III/1953, fr., Moraes 707 (IAN); ibid., s.d., fl., Vasconcelos 381 (F, R, RB); ibid., V/1953, fr., Moraes s.n. (EAN 714); Mata de Pau Ferro, III/1992, fl., Félix 4760 (EAN); ibid., III/1945, fl., Moraes s.n. (EAN 381); chã do jardim, Mata de Pau Ferro, VI/1979, fl., Fevereiro 638 (EAN, K); ibid., chã do jardim, VII/1986, fl., Félix \& Dorneles 219 (EAN).

6. Erythroxylum pulchrum A. St.-Hil., Fl. Bras. Merid. 2: 94, 1829.

Fig. 14-15

Árvore 5-10 m alt.; ramos não patentes,cinéreos, longitudinalmente estriados, recoberto por lenticelas elípticas, amareladas. Catafilos do mesmo tamanho das estípulas, esparsos nos ramos maduros e/ou adensados nas partes jovens dos ramos. Estípulas 4,5-6,0 mm compr., largo-triangulares, ápice arredondado, curtamente 3-setulosas, margem levemente ondulada, do mesmo tamanho ou maior que o pecíolo. Folha levemente discolor; pecíolo 2,5-6,0 mm compr.; lâmina foliar 44-82×30-42 mm, membranácea, largo-elíptica, ápice agudo a arredondado, base aguda a arredondada, margem plana; venação secundária, finamente reticulada, mais proeminente na face abaxial. Fascículos, 3-8 flores congestas na axila foliar.
Bractéolas 0,7-0,8 mm compr., triangulares, côncavas, membranáceas. Pedicelo 4,5-5,5 mm compr., 5-costado. Flores 3,5-4,5 mm compr., pediceladas; lobos do cálice $0,5-0,8 \mathrm{~mm}$ compr., curto-triangulares a deltóides, côncavos; pétala 4,0-4,2×1,9-2,2 mm, oblonga com a base estreitada, arredondada no ápice, côncava, amarelo-claro a creme; tubo estaminal 1,5-2,2 mm compr., maior que os lobos do cálice. Flores brevistilas: estames 2,5-3,0 mm compr.; anteras 0,3-0,4× 0,3-0,4 mm, oblongas; estiletes 0,8-1,2 mm compr., livres. Flores longistilas: estames opositissépalos 0,7-0,9 mm compr.; alternissépalos 1,0-1,4 mm compr.;.anteras ca. 0,3 mm. Ovário 2,2-2,5×0,6-0,8 mm, obovóide; estiletes 2,3-2,5 mm compr., livres. Drupa 9,0-10×3,5-4,5 mm, elipsóide, estriada longitudinalmente; pedicelo frutífero 4,5-6,0 mm.

Espécie exclusiva da flora brasileira, com distribuição no Nordeste e Sudeste do país, encontrada em Alagoas, Bahia, Ceará, Espírito Santo, Rio de Janeiro e São Paulo (Plowman \& Hensold 2004). E. pulchrum só foi encontrada na Paraíba em uma área de Floresta Serrana, em elevações de 900 a $1.000 \mathrm{~m}$ de altitude (Fig. 35F), sendo aqui sua primeira citação para o Estado. Amostras com flores foram coletadas de janeiro a março, setembro e outubro, e com frutos em janeiro, março, abril e dezembro.

Material examinado selecionado: BRASIL. Paraíba: Alagoinha, Estação Experimental de Alagoinha, V/1967, fr., Xavier s.n. (JPB 2834); Maturéia, Pico do Jabre, $7^{\circ} 11^{\prime} 10^{\prime \prime S}, 37^{\circ} 25^{\prime} 53^{\prime \prime W}$, II/1998, fl., Agra et al. 4947 (JPB); ibid., I/1998, fl., Agra et al. 4711 (JPB); ibid., sul da sede da TELPA, I/1998, fl., fr., Agra et al. 4694 (JPB); ibid., na subida para a sede da TELPA, beira da estrada, X/1997, fl., Agra 4581 (JPB); ibid., XII/1997, fr., Agra et al. 4429 (JPB); ibid., II/ 1998, fl, Agra et al. 4947 (JPB); ibid., II/1998, fl, Agra et al. 5012 (JPB); ibid., II/1998, fl., Agra et al. 5096 (JPB); ibid., X/1997, fl., Agra et al. 4542 (JPB); ibid., IV/1998, fr., Agra et al. 5456 (JPB); ibid., II/1998, fl., Agra et al. 4985 (JPB); ibid., III/1998, fr., Agra \& Silva 5122 (JPB); ibid., IV/1998, fr., Agra \& Silva 5181 (JPB); ibid., IX/1997, fl., Agra et al. 4257 (JPB); ibid., IV/1991, fr., Agra \& Barbosa 1668 (JPB); ibid., X/1997, fl., Agra \& Sr. Paulo 4805 (JPB).

7. Erythroxylum pungens O. E. Schulz, Pflanzenr. (Engler) 4(134): 49, 1907.

Fig. 11

Nome popular: rompe-gibão (Agra et al. 1696). Arbusto com até 2,7 m alt.; ramos patentes, 


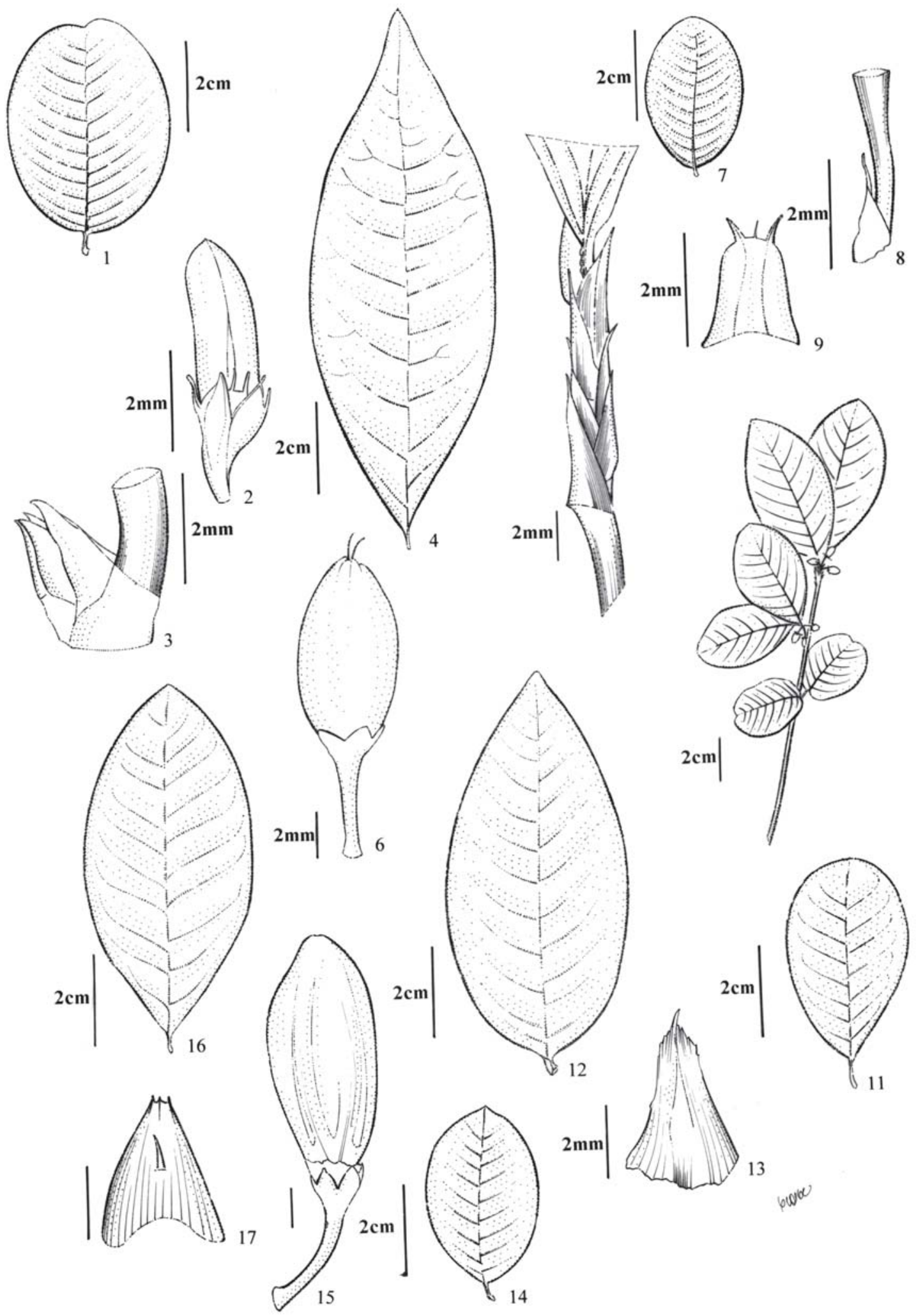

Figuras 1-17. Erythroxylum caatingae Plowman (Agra et al. 5666). 1. Folha. 2. Fruto. 3. Detalhe da inserção das estípulas na base do ramo. E. citrifolium A.St.-Hil. (Agra \& Silva 1808). 4. Folha. 5. Detalhe da inserção das estípulas na base do ramo. 6. Fruto. E. nummularia Peyr. (Agra et al. 5090). 7. Folha. 8. Inserção da bractéola no pedicelo. 9. Estípula. 10. Detalhe do ramo. E. pungens O.E. Schulz (Agra et al. 1696). 11. Folha. E. passerinum Mart. (Félix \& Santana 2529). 12. Folha. 13. Estípula. E. pulchrum A.St.-Hil. (Agra et al. 4310). 14. Folha. 15. Fruto. E. pauferrense Plowman (Felix 4760). 16. Folha. 17. Estípula. 
formando $45^{\circ}$, freqüentemente enegrecidos, às vezes cinéreos, densamente lenticelados. Catafilos do mesmo tamanho das estípulas, dísticos, congestos na base da porção jovem dos ramos e/ou em todo o ramo curto. Estípulas 1,5-2,0 $\mathrm{mm}$ compr., estriado-nervadas, triangulares, curtamente 3-setulosas, margem subfimbriada a inteira, do mesmo tamanho ou maiores que o pecíolo. Folhas levemente discolor; pecíolo 1,2-1,5 mm compr.; lâmina foliar 21,0-44,0× 11,0-27,0 mm, cartácea a coriácea, elíptica a oblongoelíptica, ápice arredondado a retuso, curtamente mucronulado, base aguda, margem plana; nervuras secundárias reticuladas, pouco proeminentes em ambas as faces. Fascículos, 1-3 flores, na axila dos catafilos. Bractéolas 0,7-0,8 $\mathrm{mm}$ triangulares, com margens fimbriadas, côncavas. Pedicelo 7,0-10,0 mm compr., 5-costado; Flores 4,0-5,0 mm compr., pediceladas; lobos do cálice 1,0-1,4×1,0-1,5 mm, oblongos, ápice acuminado a curtamente cuspidado; pétala 4,0-4,6× 2,2-2,5 mm, esbranquiçada, oboval, base truncada, plana; tubo estaminal 1-1,2×1,7-2mm, menor que os lobos do cálice. Flores brevistilas: estames 4,2-5,0 mm compr.; anteras 0,4-0,5×0,3-0,4 mm, elípticas; estiletes 1,2-1,4 mm compr., livres. Flores longistilas: estames opositissépalos 2,0-2,2 mm compr.; alternissépalos 2,5-2,7 mm compr.; anteras 0,4-0,5×0,3-0,4 mm, elípticas. Ovário 1,5-2,0×1,0-1,5 mm, obovóide; estiletes 4,0-4,2mm compr., livres. Drupa 5,5-9,0× 4,0-4,5 mm, elipsóide, sem sulcos; pedicelo frutífero $11,5-18 \mathrm{~mm}$.

De acordo com M.I.B. Loiola (dados não publicados), Erythrxoxylum pungens é uma espécie exclusiva do Nordeste do Brasil, encontrada nos Estados da Bahia, Ceará, Maranhão, Pernambuco e Piauí (Plowman \& Hensold 2004). Segundo a mesma autora, é uma espécie só encontrada no semi-árido, habitando a vegetação de caatinga. Sua ocorrência na Paraíba está sendo aqui referida pela primeira vez, registrada de apenas uma coleta realizada em um enclave de Floresta Serrana (Fig. 35G), na caatinga, em elevações de 300 a $500 \mathrm{~m}$ de altitude. Amostras com flores foram coletadas em janeiro.

Material examinado selecionado: BRASIL. Paraíba: Aguiar, limite leste da serra de Santa Catarina, I/1999, fl., Barbosa et al. 1800 (JPB); Itaporanga, caminho para Serra Água Branca, III/1993, est., Agra et al.1696 (IPA, JPB).

8. Erythroxylum revolutum Mart., Beitr. Erythroxylon $71,1840$.

Fig. 18-20
Arbusto a arvoreta, 0,8-3 m alt.; ramos não patentes, estriados longitudinalmente, cinéreos, densamente revestidos por lenticelas amareladas ou alvas, elípticas. Catafilos do mesmo tamanho das estípulas, aleatoriamente distribuídos nos ramos. Estípulas 1,5-3,0 mm compr., estriado-nervadas, deltóides, curtamente 3-setulosas, margem inteira, do mesmo tamanho do pecíolo. Folha levemente discolor; pecíolo 2,5-3,5 mm compr.; lâmina 30-65×14-34 mm, coriácea, oblongo-elíptica a oboval, discolor, ápice agudo a obtuso, base aguda, margens frequientemente revolutas, venação secundária reticulada, proeminente em ambas as faces. Fascículos, 1-3 flores, na axila dos catafilos. Bractéolas 0,6-0,9 mm compr., triangulares, côncavas, cartáceas. Pedicelo diminuto, menos de 0,5 mm compr. Flores 3,4-4,0 mm, subsésseis; lobos do cálice 1,0-1,2×1,0-1,2 mm, deltóides; pétala 3,0-4,0×1,2-1,5 mm, amarelada a branca, oblonga, côncava; tubo estaminal 1,0-1,2×1,2-1,5 mm, do mesmo tamanho ou menor que os lobos do cálice. Flores brevistilas: estames 3,0-3,5 mm compr.; anteras 0,6-0,7×0,4-0,5 mm, elípticas; estiletes 1,2-2,0 mm compr., livres; Flores longistilas: estames opositissépalos 1,9-2,1 mm compr.; alternissépalos 2,6-3,1 mm compr.; anteras 0,4-0,5× 0,4-0,5 mm, elípticas. Ovário 1,2-1,4×1,0-1,2 mm, obovóide; estiletes 5,0-6,0 mm compr., livres. Drupa não observada.

Espécie exclusiva do Brasil, com distribuição restrita à região Nordeste encontrada em áreas do semi-árido (caatinga) nos Estados de Alagoas, Bahia, Ceará, Pernambuco, Piauí e Sergipe (M.I.B. Loiola, dados não publicados). Na Paraíba E. revolutum está registrada em apenas duas coletas em áreas de caatinga (Fig. 36A), constituindo-se em uma nova citação para o Estado. Amostras com flores foram coletadas em fevereiro e março e com frutos em março.

Material examinado selecionado: BRASIL. Paraíba: Esperança, XII/1986, fl., Félix \& Dorneles 1665 (EAN, JPB); Serra Branca, base da pedra da serra, 8-11/III/2002, fl., fr., Agra et al. 5695 (JPB).

9. Erythroxylum rimosum O.E. Schulz, Pflanzenr. (Engler) 4(134): 53, 1907.

Fig. 21-22

Arbustos 0,6-1,0 m altura; ramos não patentes, cinéreos, raro lenticelados. Catafilos do mesmo amanho das estípulas, numerosos, adensados na base da porção jovem dos ramos. Estípulas 2,0-2,5 mm compr., estriado-nervadas, triangulares, ápice acuminado, curtamente 3 -setulosas, margem inteira a esparsamente 
erosa, maiores que o pecíolo. Folha levemente discolor; pecíolo 1,0-1,5×0,6-1,0 mm; lâmina 33-55×12-27 mm, cartácea, elíptica ou oblonga, ápice agudo a arredondado, base aguda, margem plana; venação secundária finamente reticulada, impressa na face adaxial e levemente proeminente na face abaxial. Fascículos, 6-10 flores, congestas, na axila dos catafilos. Bractéolas 0,6-1,0×0,5-0,6 mm compr., triangulares, côncavas, membranáceas. Pedicelo 7,0-9,0 mm compr., 4-6-costado. Flores 3,5-4,0 mm compr., pediceladas; lobos do cálice 1,2-1,5×1,5-2,0 mm, oblongos a obovais, levemente erosos na margem, ápice acuminado; pétala 4,0-5,0×1,8-2,0 mm, amarela, oboval, arredondada no ápice; tubo estaminal 1,0-1,2 mm compr., menor que os lobos do cálice. Flores brevistilas não observadas. Flores longistilas: estames opositissépalos 2,8-3,0 mm compr.; alternissépalos 1,8-2,0 mm compr.; anteras 0,4-0,5×0,4-0,5 mm, arredondadas. Ovário 0,4-0,6× 1-1,2 mm diâm., ovóide; estiletes 4,0-5,0 mm compr., livres. Fruto não observado.

Espécie restrita à região Nordeste do Brasil, encontrada apenas nos estados do Ceará, Piauí e Sergipe, ocorrendo respectivamente em vegetação de restinga, cerrado e carrasco (M.I.B. Loiola, dados não publicados). Na Paraíba, a espécie foi coletada no litoral, em áreas de restinga (Fig. 36B). E. rimosum assemelha-se a E. suberosum var. denudatam, com a qual pode ser confundida. Entretanto, estas duas espécies podem ser separadas pela morfologia das folhas e flores: E. rimosum possui as folhas cartáceas, elípticas a oblongas, com venação secundária impressa na face adaxial e proeminente na face abaxial e as flores longistilas possuem estiletes livres; em $E$. suberosum var. denudatum as folhas são coriáceas, obovais, com venação secundária pouco evidente em ambas as faces e os estiletes das flores longistilas são unidos na base. Amostras floridas foram coletadas em fevereiro, abril, outubro e novembro.

Material examinado selecionado: BRASIL. Paraíba: Caaporã, Capim de Cheiro, IX/1981, est., Moura s.n. (JPB 479); Conde, Praia de Jacumã, XI/1991, fl., Moura 690 (JPB); João Pessoa, próx. IBDF, X/1979, fl., Agra 183 (JPB); Lucena, Faz, N. Sra. da Guia: II/1994, fl., Moura 1198 (JPB); Mamanguape: Sema I, IV/1989, fl., Félix \& E. Santana 3554 (JPB); ibid., Capim Azul, III/1990, fl., Félix \& Santana 2792 (JPB); Miriri, BR-130, II/1989, fl., Agra \& Góis 691 (JPB); Santa Rita, IV/1993, fl., Agra 1857 (JPB, UFRPE); ibid., 757'S, 3500'15W, IV/1993, fl., Agra et al. 1856 (JPB); ibid., km 51, IV/1981, fl., Agra 330 (JPB).
10. Erythroxylum simonis Plowman, Brittonia 38(3): 189, f. 1, 1986.

Fig. 23-26

Nome popular: guarda-orvalho (Plowman 1986).

Arbusto a arvoreta, 2,0-2,5 m; ramos não patentes, rugosos, cinéreos a castanho-cinéreos, recobertos por lenticelas amareladas; ramos curtos ausentes. Catafilos do mesmo tamanho das estípulas, esparsos ao longo dos ramos e/ou congestos na base da porção jovem dos ramos. Estípulas 1,5-3,0 mm compr., estriadonervadas, triangulares, 3 -setulosas, margem inteira, do mesmo tamanho do pecíolo. Folhas levemente discolor; pecíolo 2,0-3,0 mm compr.; lâmina 26-57×13-24 mm, cartácea, elíptica a oboval, ápice acuminado a agudo, base aguda, margem plana; venação secundária reticulada, impressa na face adaxial, proeminente na face abaxial. Fascículos, 1-5 flores na axila das folhas e/ou catafilos. Bractéolas largamente ovóides, côncavas. Pedicelo 3,5-6,0 mm compr. Flores 5,0-7,5 mm compr., pediceladas; lobos do cálice 0,4-0,6×0,6-0,8 mm, deltóides; pétala 2,0-3,5× 1,2-1,5 mm, alva a amarelada, oblonga a elíptica, ápice arredondado a plano, alvacenta a amarelada; tubo estaminal 1,0-1,3×1,2-1,5 mm, maior que os lobos do cálice. Flores brevistilas: estames 2,0-3,0 mm compr.; anteras $0,4-0,5 \times 0,5-0,6 \mathrm{~mm}$, suborbiculares; estiletes 0,7-0,8 mm compr., livres. Flores longistilas: estames opositissépalos 0,5-0,6 mm compr.; alternissépalos 0,8-1,2 mm compr.; anteras 0,4-0,5×0,4-0,5 mm, suborbiculares. Ovário 1,1-1,7×0,9-1,5 mm, obovóide a subgloboso; estiletes 1,7-1,8 mm, livres. Drupa 8-9×5,0-5,7 mm, oblongo-obovóide a largo-elipsóide, sem sulcos, vermelha quando madura; pedicelo frutífero ampliado 4,0-6,5 $\mathrm{mm}$.

Espécie restrita ao nordeste brasileiro, com ocorrência confirmada para a Paraíba (Fig. 36C), local do espécime tipo, Pernambuco, Ceará e Sergipe, encontrada em florestas úmidas da Floresta Atlântica e dos Brejos de Altitude (M.I.B. Loiola, dados não publicados). E. simonis possui grande afinidade com E. pauferrense, espécie com a qual compartilha alguns caracteres morfológicos e o mesmo habitat, cujos caracteres diferenciais já foram citados anteriormente. Amostras com flores foram coletadas em março, maio, junho e outubro, amostras com frutos em abril, maio, outubro e novembro.

Material examinado selecionado: BRASIL. Paraíba: Areia, Mata de Pau Ferro, 658’12”S, $35^{\circ} 42^{\prime} 15^{\prime}$ 'O, Chã do Jardim, área atrás da casa do vigia, 28/XI/1980, fr, Fevereiro et al. M128 (EAN, K, NY); ibid., 658'12”S, 3542’15”W, X/1980, fl., 
Fevereiro M67 (EAN, F, IAN, IPA, JPB, K, P, R, SP); ibid., III/1992, fl., Félix 4747 (EAN); V/1953, fl., Moraes s.n. (EAN 707); ibid., X/1988, fr., Félix \& Dornelles 1412 (JPB); ibid., V/1980, fr., AndradeLima et al. M4 (EAN); ao lado do caminho para barragem, XI/1980, st., Fevereiro et al. s.n. (EAN 3498); Itapororoca, Fazenda Macacos, IV/1992, fr., Félix 4830 (EAN); João Pessoa, 6 km N de João Pessoa, VI/1984, fl., Kesselring s.n. (F 1926696); ibid., Campus I, UFPB, V/1993, fl., Neto 20 (JPB); Lagoa Seca, Fazenda Ipuarana, VII/2001, fr., Lourenço \& Carneiro 232 (JPB).

11. Erythroxylum squamatum Sw., Prodr. (DC.) 75, 1788.

Fig. 27-30

Arvoreta, ca. 2-2,5 m alt.; ramos não patentes, castanho-avermelhados quando jovens, ramos adultos cinéreos. Catafilos do mesmo tamanho ou maiores que as estípulas, dísticos, numerosos e adensados (escamiformes) na base dos ramos jovens ou curtos, coriáceos nos ramos jovens e curtos, lenhosos no ramo maduro. Estípulas 2,0-2,5 mm compr., estriadonervadas, triangulares, deltóides, com ápice acuminado, 1-setulosa, margem inteira, menores que o pecíolo. Folha levemente discolor; pecíolo 3-5 mm compr., marrom-escuro; lâmina 60-130×35-50 mm, cartácea a subcoriácea, elíptica a ob-elíptica, base aguda, ápice cuspidado, margem plana, ferrugínea em ambas as faces, lúcida na face adaxial e opaca na abaxial; venação principal subimpressa na face adaxial, proeminente na face abaxial; venação secundária reticulada, impressa na face adaxial, proeminente na face abaxial. Fascículos, 7-10 flores. Bractéolas 1,0-1,1×0,5-0,6 mm, triangulares, côncavas. Pedicelo 3,5-4,5 mm compr. na antese, 4,0-4,5 mm nas flores mais velhas, 5-costado. Flores 9,0-11 mm compr., pediceladas; lobos do cálice 2,0-2,2×1,0-1,5 mm, deltóides; pétala 4,0-5,0×2,5-3,0 mm, alvacenta a amarelada, oval-oblonga, ápice arredondado; tubo estaminal 1,1-1,3×1,8-2,0 mm, menor ou do mesmo tamanho dos lobos do cálice. Flores brevistilas não observadas. Flores longistilas: estames opositissépalos, 1,0-1,4 mm compr.; anteras 0,4-0,5×0,3-0,4 mm, orbiculares; estames alternissépalos 2,0-2,2× 0,8-1,2 mm; anteras 0,4-0,5×0,4-0,5 mm, suborbiculares. Ovário 1,2-1,4×1,4-1,6 mm, subgloboso; estiletes 0,8-0,9 mm, livres. Drupa 13-15×3,0-5,0 mm, oblongoelipsóide, 6-sulcada longitudinalmente, verde quando imatura e vermelha na maturidade; pedicelo frutífero ampliado 7,0-10 mm compr., levemente 6-7-costado.
De acordo com M.I.B. Loiola (dados não publicados), E. squamatum é uma espécie neotropical, nativa da América do Sul, com distribuição na Venezuela, Peru, Equador, Guianas, Bolívia e Brasil (Amapá, Amazonas, Bahia, Ceará, Maranhão, Mato Grosso, São Paulo e Sergipe). Na Paraíba a espécie é conhecida de apenas duas coletas, ambas em remanescentes de Floresta Atlântica (Fig. 36D), no município de João Pessoa, constituindo-se de sua primeira citação para o Estado. Amostras com frutos foram coletadas nos meses de abril e maio.

Material examinado selecionado: BRASIL. Paraíba: João Pessoa, Cidade Universitária, próximo ao Biotério, IV/1991, fr., Moura 579 (JPB); ibid., Mata do Buraquinho, interior da mata, 4/V/1995, fl., fr., Barbosa et al. 1469 (JPB).

12. Erythroxylum suberosum var. denudatum O.E. Schulz, in Engler, Pflanzenr. 4(134): 28, 1907.

Fig. 31-32

Arbustos 1-1,5 m altura; ramos não patentes, cinéreos a castanhos, com fissuras avermelhadas, lenticelas pouco evidentes, elípticas, ferrugíneas. Catafilos do mesmo tamanho das estípulas, numerosos, adensados na base da porção jovem dos ramos. Estípulas 2,0-3,5 mm compr., maiores que o pecíolo, estriado-nervadas, triangulares, ápice arredondado, curtamente 3-setulosas, margem inteira,. Folhas discolor; pecíolo 1,5-2,5×1,0-15 mm; lâmina $38-62 \times$ 21-37 mm, coriácea, obovada, ápice arredondado, às vezes emarginado, mucronulado, base aguda, margem plana; venação secundária reticulada, pouco evidente em ambas as faces. Fascículos com 1-3 flores laxas, na axila dos catafilos. Bractéolas 1,0-1,2×0,8-0,9 mm compr., ovóides, côncavas. Pedicelo 6,5-8,0 mm compr., 5-costado. Flores 3,5-4,0 mm compr., pediceladas; lobos do cálice 1.0-1,2×0,7-0,9 mm, oblongos a obovais, com ápice em geral curtamente acuminado; pétala 3,0-4,2×1,5-2,0 mm, alva a amarelo-claro, oval-oblonga, alva a amarelo-claro; tubo estaminal 1,1-1,5 mm compr., menor que os lobos do cálice. Flores brevistilas: estames 4,0-4,5 mm compr.; anteras 0,5-0,6× 0,4-0,5 mm, oblongas; estiletes 1,0-1,3 mm compr., livres. Flores longistilas: estames opositissépalos 1,2-1,5 mm compr.; alternissépalos 1,8-2,0 mm compr.; anteras $0,5-0,6 \times 0,4-0,5 \mathrm{~mm}$, oblongas. Ovário 1,5-2,0×1,0-1,2 mm diâm., largo-ovóide; estiletes 2,5-3,5 mm compr., unidos na base. Drupa jovem 5,0-6,5×2,0-4,0 mm, oval-elíptica; pedicelo frutífero ampliado 5,0-7,0 mm compr., 5-6-costado. 

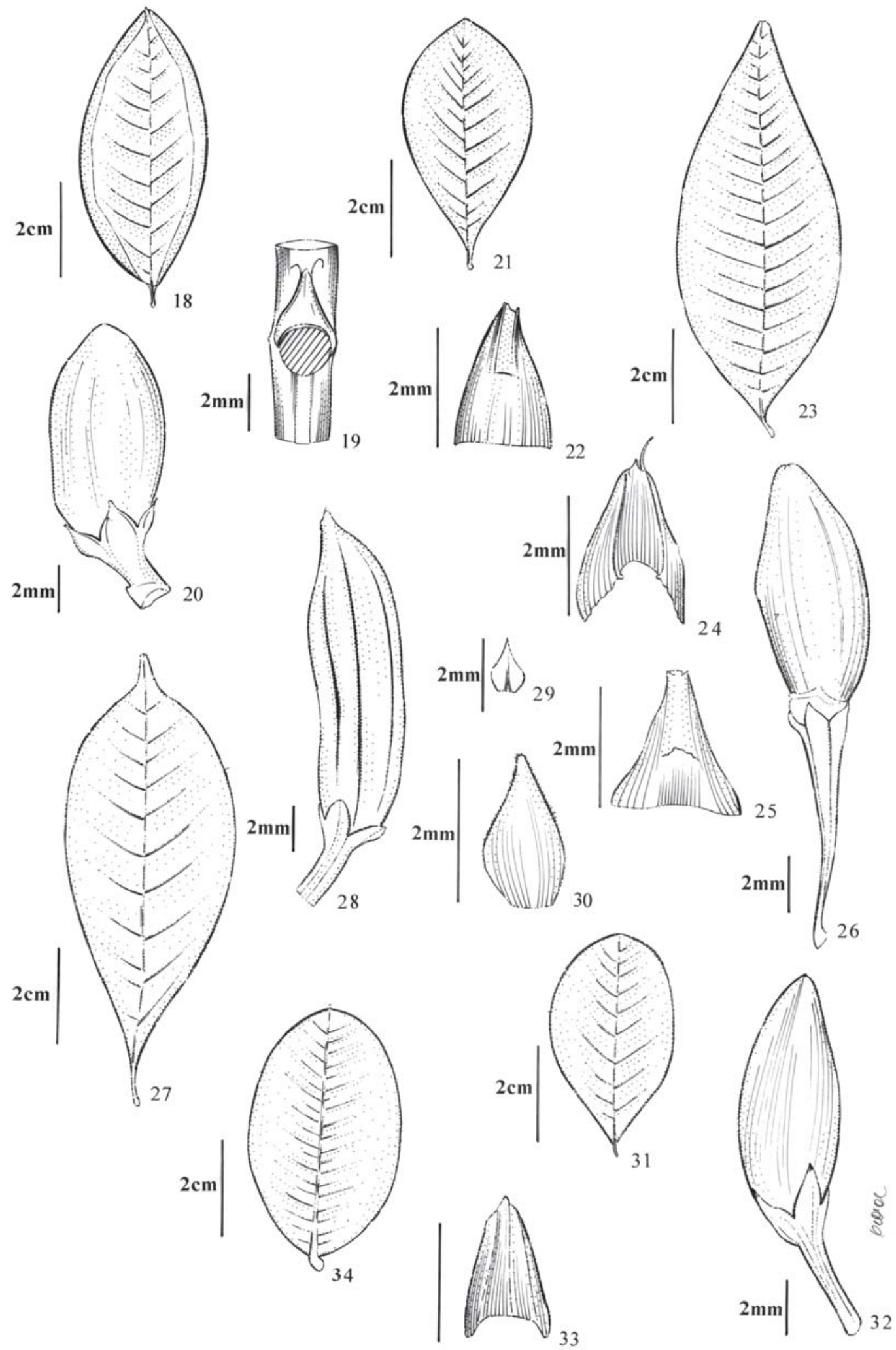

Figuras 18-34. E. revolutum Mart. (Agra et al. 5695). 18. Folha. 19. Detalhe da inserção da estípula no pecíolo (cicatriz hachurada). 20. Fruto. E. rimosum O.E. Schulz. (Agra \& Góis 691). 21. Folha. 22. Estípula. E. simonis Plowman (Agra \& Góis 5495). 23. Folha. 24. Estípula. 25. Estípula. 26. Fruto. E. squamatum Sw. (Barbosa et al. 1469). 27. Folha. 28. Fruto. 29. Bractéola da inflorescência. 30. Sépala. E. subrotundum A.St.-Hil. (Agra et al. 4958). 31. Folha. 32. Fruto. E. suberosum var. denudatum O.E. Schulz (Felix \& Dornelas 1665). 33. Estípula. 34. Folha. 
Erythroxylum suberosum var. denudatum pode ser facilmente reconhecida pelas folhas coriáceas e obovais com nervuras pouco evidentes em ambas as faces e lobos do cálice obovais a oblongos com ápice curto acuminado. De acordo com Plowman \& Hensold (2004), apresenta distribuição no norte do Brasil (Alagoas, Bahia, Espírito Santo, Goiás, Maranhão, Mato Grosso, Minas Gerais, Pará, Paraíba e Pernambuco). Na Paraíba, ocorre preferencialmente em ambientes de solos arenosos e em vegetação de tabuleiro (Fig. 36E). Amostras com flores foram coletadas em fevereiro e junho e com frutos em fevereiro.

Material examinado selecionado: BRASIL. Paraíba: Conde, Praia de Jacumã, VI/1991, fl., Moura 601 (JPB); Santa Rita, 23/II/1989, fr., Agra 689 (JPB).

13. Erythroxylum subrotundum A. St.-Hil., Pl. Usuel. Bras. 3, t. 69, 1828.

Fig. 31-32

Arvoreta 2,5 m alt.; ramos não patentes, castanhoavermelhados quando jovens; ramos maduros adultos cinéreos, densamente recobertos por lenticelas elípticas, brancas a amareladas; ramos jovens castanhoavermelhados. Catafilos do mesmo tamanho das estípulas, distribuídos densamente na base dos ramos jovens. Estípulas 2-2,5 mm compr., semelhantes aos catafilos, enérveas, triangulares, ápice truncado a arredondado, 2-setulosas, margem inteira a subfimbriada, do mesmo tamanho ou maiores que o pecíolo. Folha levemente discolor; pecíolo 1,0-2,0 mm compr.; lâmina foliar 24-48×16-30 mm, membranácea, obovada, largo-elíptica a suborbicular, ápice arredondado, base aguda, margem plana; verde-claro em ambas as faces, lúcida na face adaxial e opaca na face abaxial; nervura principal subimpressa na face adaxial, proeminente na face abaxial; venação secundária impressa na face adaxial, proeminente na face abaxial. Fascículos com 1-6 flores, na axila dos catafilos. Bractéolas 1,0-1,5 mm, ovóides, margem fimbriada, côncavas. Pedicelo 5,5-4,0 mm compr., 5-costado. Flores 4,0-6,0 mm compr., pediceladas; lobos do cálice 1,0-1,2× 0,8-1,0 mm, triangulares, côncavas; pétala 3,5-4,0× 1,5-2,0 mm, creme a amarelada, elíptica a obovada, plana; tubo estaminal 1,2-1,5×1-1,5 mm, menor que os lobos do cálice. Flores brevistilas: não observadas. Flores longistilas: estames opositissépalos 1,0-1,5 mm compr.; alternissépalos 2,0-2,2 mm compr.; anteras 0,3-0,4×0,4-0,5 mm, elípticas. Ovário 1,0-1,5× 0,9-1,2 mm, obovóide; estiletes 3,5-4 mm, livres. Drupa 6,5-7,5×3-3,5 mm, obovóide, estriada longitudinalmente, verde quando imatura e vermelha na maturidade; pedicelo frutífero 4,0-5,2 mm compr., 5-costado.

E. subrotundum é facilmente reconhecida pelas folhas membranáceas, obovadas a largamente elípticas, às vezes suborbiculares, com ápice arredondado, lúcida

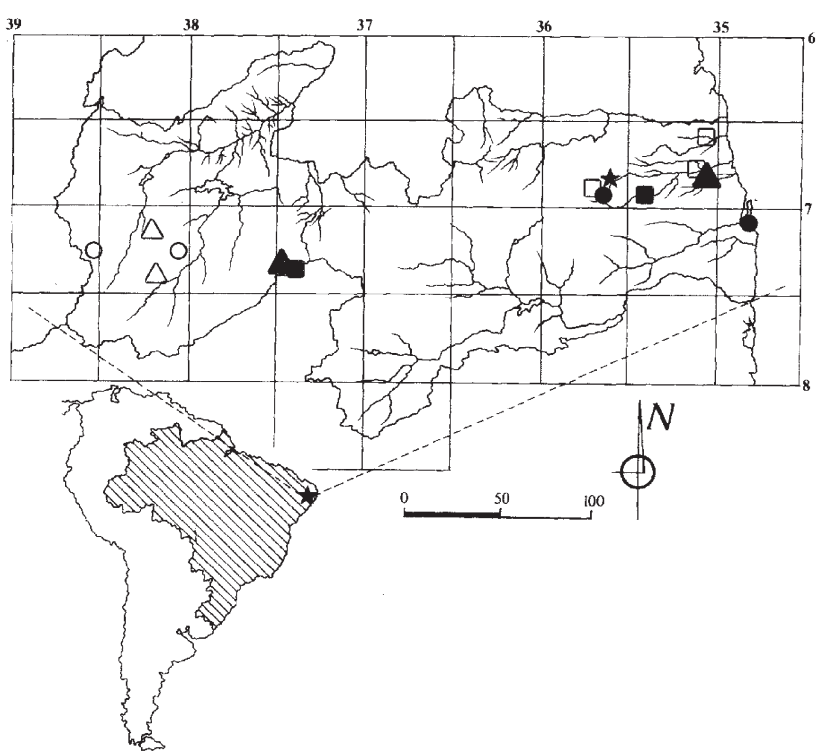

Figura 35. Mapa de distribuição das Erythroxylaceae na Paraíba, Brasil: A. Erythroxylum caatingae Plowman (o); B. E. citrifolium A.St.-Hil. (•); C. E. nummularia Peyr. (৫); D. E. passerinum Mart. (口); E. E. pauferrense Plowman ( $\star)$; F. E. pulchrum A.St.-Hil. (๘); G. E. pungens O.E.Schulz $(\triangle)$.

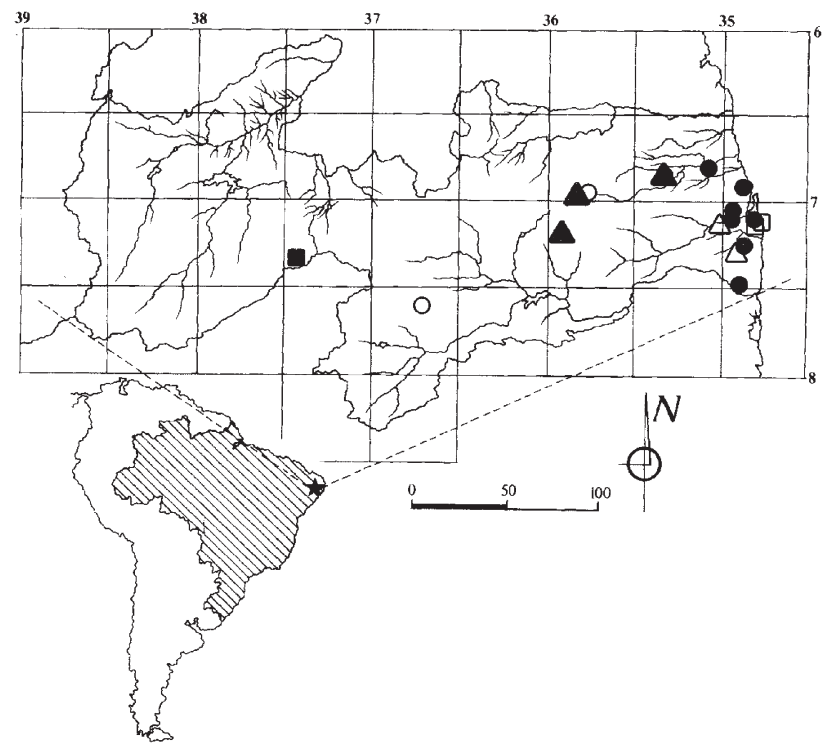

Figura 36. Mapa de distribuição das Erythroxylaceae na Paraíba, Brasil: A. E. revolutum Mart. (o); B. E. rimosum O.E. Schulz. $(\bullet)$; C. E. simonis Plowman (४); D. E. squamatum Sw. (口); E. E. suberosum var. denudatum O.E. Schulz $(\Delta)$; F. E. = subrotundum A. St.-Hil. (๘). 
na face adaxial e opaca na face abaxial. Tem ocorrência em Alagoas, Bahia, Ceará, Distrito Federal, Espírito Santo, Goiás, Minas Gerais, Pernambuco, Rio Grande do Norte e Rio de Janeiro (M.I.B. Loiola, dados não publicados). Espécie rara na Paraíba, somente conhecida de uma coleta realizada em área de Floresta Serrana, sendo aqui sua primeira citação para o Estado (Fig. 36F). Amostras com frutos foram coletadas em fevereiro.

Material examinado selecionado: BRASIL. Paraíba: Maturéia, Pico do Jabre, $7^{\circ} 11^{\prime} 10^{\prime \prime S}$, 37²5'53”'W, 7-10/II/1998, fr., Agra et al. 4958 (JPB).

Material adicional: BRASIL. Pernambuco: Floresta, Inajá, Reserva Biológica de Serra Negra, 8/II/1995, fl., M. C. Tschá et al. 14 (PEUFR).

O Estado da Paraíba está bem representado pelo gênero Erythroxylum que possui 13 espécies o que corresponde à cerca de $11,4 \%$ das espécies encontradas no Brasil. Nesse estudo são apontadas seis novas ocorrências de Erythroxylum para a Paraíba: E. nummularia, E. passerinum, E. pulchrum, E. pungens, E. revolutum e E. squamatum. A maioria das espécies (sete) apresenta distribuição restrita à região Nordeste do país (E. caatingae, E. nummularia, E. pauferrense, E. pungens, E. revolutum, E. rimosum, E. simonis), sendo E. pauferrense exclusiva do estado da Paraíba, registrada apenas no município de Areia.

\section{Agradecimentos}

Os autores agradecem ao Conselho Nacional de Pesquisas e Desenvolvimento (CNPq), pelas bolsas concedidas a M.F. Agra (PQ) e G.S. Baracho (DTI); aos curadores dos herbários nacionais e internacionais, pelo empréstimo do material examinado e livre acesso às suas dependências para exame das coleções.

\section{Referências bibliográficas}

Alagille, D.; Baldwin, R.M; Roth, B.L.; Wroblewski, J.T.; Grajkowska, E. \& Tamagnan, G.D. 2005. Functionalization at position 3 of the phenyl ring of the potent mGluR5 noncompetitive antagonists MPEP. Bioorganic \& Medicinal Chemistry Letters 15: 945-949.

Amaral, A. 1980. Erythroxylaceae. In: R. Reitz (ed.) Flora Ilustrada Catarinense. Parte I, fasc. ERIT: 1-64.

Amaral, A. 1990. A new species of Erythroxylum P. Browne (Erythroxylaceae) from the state of Espírito Santo, Brazil. Naturalia 15: 147-152.
Amaral, A. \& L.S. Leoni. 1992. O gênero Erythroxylum P. Browne (Erythroxylaceae) no município de Carangola, Minas Gerais. Pabstia 3(3): 1-5.

APG. 1998. An ordinal classification for the families of flowering plants. Annals of the Missouri Botanical Garden 85: 531-553.

APG. 2003. An update of, APG classification for the orders and families of flowering plants. Botanical Journal of the Linnean Society 141: 399-436.

Brummitt, R.K. \& Powell, C.E. 1992. Authors of Plant Names. Royal Botanic Gradens, Kew.

Barbosa, A.V.G. \& A. Amaral. 2001. Erythroxylaceae. In: J.A. Rizzo (Ed.). Flora dos estados de Goiás e Tocantins 29: 9-73.

Bohm, B.A.; Ganders, F.R. \& Plowman, T. 1982. Biosystematics and evolution of cultivated coca (Erythroxylaceae). Systematic Botany 7: 121-133.

Cronquist, A. 1981. An Integrated System of Classification of Flowering Plants. New York, Columbia University Press.

Daly, D. 2004. Erythroxylaceae. Pp.143-145. In: N. Smith; S.A. Mori, A. Henderson et al. (eds.). Flowering Plants of Neotropics. USA, The New York Botanical Garden. Princeton University Press.

Griffin, W.J. \& Lin, G.D. 2000. Chemotaxonomy and geographical distribution of tropane alkaloids. Phytochemistry 53: 623-637.

Dahlgren, R.M.T. 1988. Rhizophoraceae and Anisophylleaceae: summary statement, relationships. Annals of the Missouri Botanical Garden 75: 1259-1277.

Judd, W.S. \& Olmstead, R.G. 2004. A survey of tricolpate (eudicot) phylogenetic relationships. American Journal of Botany 91(10): 1627-1644.

Holmgren, P.K.; Holmgren, N.H. \& Barnet, L.C. 1990. Index Herbariorum, Part I. The Herbaria of the World. 8 ed. USA, The New York Botanical Garden Press.

Loiola, M.I.B. 2004. Flora de Grão Mongol, Minas Gerais: Erythroxylaceae. Boletim de Botânica da Universidade de São Paulo 22(2): 101-108.

Martius, K.F.P. 1843. Erythroxylon. Abhandlungen der Königlichen Bayerischen Akademie der Wissenschaften 3(2): 280-410.

Nurit, K.; Agra, M.F.; Basílio, I.J.L.D. \& Baracho, G.S. 2005. Flora da Paraíba, Brasil: Loganiaceae. Acta Botanica Brasilica 19(2):407-416.

Peyritsch, J. 1878. Erythroxylaceae. In: C.F.P. Martius (ed.). Flora Brasiliensis 12(1): 125-180.

Plowman, T.C. 1983, New species of Erythroxylum from Brazil and Venezuela. Botanical Museum Leaflets 29. 273-290.

Plowman, T.C. 1984. New taxa of Erythroxylum (Erythroxylaceae) from the Amazon basin. Acta Amazonica 14(1/2) Supl.: 117-143.

Plowman, T.C. 1986. Four new species of Erythroxylum (Erythroxylaceae) from northeastern Brazil. Brittonia 38(3): 189-200.

Plowman, T.C. 1987. Ten new species of Erythroxylum (Erythroxylaceae) from Bahia, Brazil. Fieldiana: Botany. Chicago [Field Museum of Natural History] 19: 1-41. 
Plowman, T.C. \& Berry, P.E. 1999. Erythroxylaceae. In: J. Steyermark; P. Berry; B. Holst \& K. Yatskievych (eds.). Flora of the Venezuelan Guayana 5: 59-71. St. Louis, Missouri Botanical Garden Press.

Plowman, T.C. 2001. Erythroxylaceae Kunth. In: W.D. Stevens; C. Ulloa; A. Pool \& O.M. Montiel (eds.). Flora de Nicaragua. Monographs Systematic Botany Missouri Botanical Garden 85: 834-838.

Plowman, T.C. \& Hensold, N. 2004. Names, types and distribution of neotropical species of Erythroxylum (Erythroxylaceae). Brittonia 56(1): 1-53.

Savolainen, V.; Chase, M.W.; Hoot, S.B.; Morton, C.M.; Soltis, D.E.; Bayer, C.; Fay, M.F.; De Bruijn, A.Y.; Sullivan, S. \& Qiu, Y.-L. 2000. Phylogenetics of flowering plants based upon a combined analysis of plastid $a t p B$ and $r b c L$ gene sequences. Systematic Biology 49: 306-362.

Schulz, O.E. 1907. Erythroxylaceae. In: A. Engler (ed.). Das Pflanzenreich 4(134): 1-164.

Schwarzbach, A.E. \& Ricklefs, R.E. 2000. Systematic affinities of Rhizophoraceae and Anisophylleaceae, and intergeneric relationships within Rhizophoraceae, based on Chloroplast dna, nuclear ribosomal dna, and morphology. American Journal of Botany 87(4): 547-564.
Soltis, D.E.; Soltis, P.S.; Chase, M.W.; Mort, M.E.; Albach, D.C.; Zanis, M.; Savolainen, V.; Hahn, W.H.; Hoot, S.B; Fay, M.F.; Axtell, M.; Swensen, S.M; Prince, L.M.; Kress, W.J.; Nixon, C.K. \& Farris, J.S. 2000. Angiosperm phylogeny inferred from $18 \mathrm{~S}$ rDNA, $r b c L$, and $a t p B$ sequences. Botanical Journal of the Linnean Society 133: $381-461$.

Stebbins, G.L. 1974. Flowering Plants: Evolution Above The Species Level. Cambridge, Massachusetts, The Belknap Press of Harvard University Press.

Thorne, R.T. 2000. The Classification and Geography of the Flowering Plants: Dicotyledons of the Class Angiospermae (Subclasses Magnoliidae, Ranunculidae, Caryophyllidae, Dilleniidae, Rosidae, Asteridae, and Lamiidae). The Botanical Review 66(4): 441-647.

Vicentini, A. \& Prance, G. 1999. Erythroxylaceae. P. 500. In: J.E.L.S. Ribeiro; M.J.G. Hopkins \& A. Vicentini (eds.). Flora da Reserva Ducke. Guia de Identificação das Plantas Vasculares de uma Floresta de Terra-firme na Amazônia Central. Manaus, INPA.

Zappi, D.C. 1995. Erythroxylaceae. Pp. 297-299. In: B.L. Stannard (ed.). Flora of the Pico das Almas, Chapada Diamantina, Bahia, Brazil. Kew, Royal Botanic Gardens. Zuanazzi, J.A.S.; Tremea, V.; Limberger, R.P; Sobral, M. \& Henriques, A.T. 2001. Biochemical Systematics and Ecology 29: 819-825. 